Ophthalmic Res 1997;29:237-239

\title{
Contents, Vol. 29, No. 5, 1997
}

\section{Editorial}

Wiedemann, P.; Kohen, L. (Leipzig)

242 Ocular Gene Therapy: Experimental

Studies and Clinical Possibilities

Murata, T.; Kimura, H.; Sakamoto, T.; Osusky, R.; Spee, C; Stout, T.J.; Hinton, D.R.; Ryan, S.J. (Los Angeles, Calif.)

252 Molecular Elucidation of Hereditary Eye Diseases: Pivotal Role of the Clinician

Ropers, H.H. (Nijmegen/Berlin)

261 Gene Therapy for Retinal Degeneration

Reichel, M.B. (Leipzig/London); Ali, R.R.; Hunt, D.M.: Bhattacharya, S.S. (London)

269 The Development of Subretinal

Microphotodiodes for Replacement of Degenerated Photoreceptors

Zrenner, E.; Miliczek, K.-D. (Tubingen); Gabel, V.P. (Regensburg); Graf, H.G. (Stuttgart);

Guenther, E.; Haemmerle, H. (Tubingen); Hoefflinger, B. (Stuttgart); Kohler, K.; Nisch, W.

(Tubingen); Schubert, M. (Stuttgart); Stett, A.; Weiss, S. (Tubingen)

281 Learning Retina Implants with Epiretinal Contacts

Eckmiller, R. (Bonn)

290 Photoreceptor Transplants Increase Host Cone Survival in the Retinal Degeneration (rd)

Mouse

Mohand-Said, S.; Hicks, D.; Simonutti, M.; Tran-Minh, D.; Deudon-Combe, A.; Dreyfus, H. (Strasbourg); Silverman, M.S.; Mosinger Ogilvie, J.; Tenkova, T. (St. Louis, Mo.); Sahel, J.

(Strasbourg)

298 Mechanisms of Graft Rejection in the Transplantation of Retinal Pigment Epithelial Cells

Kohen, L.; Enzmann, V.; Faude, F.; Wiedemann, P. (Leipzig)

305 Intraretinal Transplantation to Prevent Photoreceptor Degeneration

Lund, R.D. (London); Coffey, P.J. (Sheffield); Sauvé, Y.; Lawrence, J.M. (London)

320 Blood Supply of the Retina

Funk, R.H.W. (Dresden)

326 The Müller (Glial) Cell in Normal and Diseased Retina: A Case for Single-Cell

Electrophys;ology

Reichenbach, A.; Faude, F.; Enzmann, V.; Bringmann, A.; Pannicke, T.; Francke, M.;

Biedermann, B.; Kuhrt, H; Stolzenburg, J.-U. (Leipzig); Skatchkov, S.N. (Bayamon, P.R.);

Heinemann, U. (Berlin); Wiedemann, P.; Reichelt, W. (Leipzig)

341 Growth Factors in Age-Related Macular Degeneration: Pathogenic and Therapeutic

Implications

Frank, R.N. (Detroit, Mich.)

354 Vascular Endothelial Growth Factor and the Eye: Biochemical Mechanisms of Action and Implications for Novel Therapies

Aiello, L.P. (Boston, Mass.) 
Author Index

Subject Index

KARGEfl

E-Mail karger@karger.ch Fax+4161 3061234 http://www.karger.ch

(C) 1997 S.KargerAG, Basel

The list of contents is available at: http://www.karger.ch/journals/ore/orecont.htm 239 